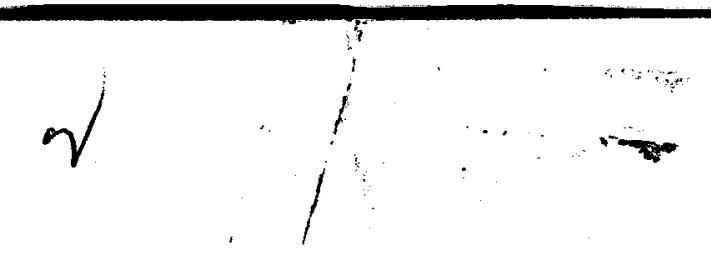

This is an informal report intended primarily for internal or limited external distribution. The opinions and conclusions stated are those of the author and may or may not be those of the laboratory.

UCID - 16631

\author{
㢟 \\ LAWRENCE LIVERMORE LABORATORY \\ University of California/Livermore, California
}

\title{
A METHODICAL APPROACH TO TEMPERATURE \\ AND PRESSURE MEASUREMENTS \\ FOR IN SITU ENERGY-RECOVERY PROCESSES
}

R. H. Cornell

November 14, 1974

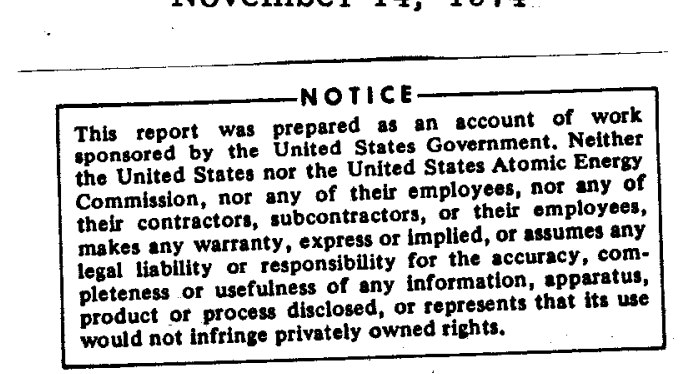

Prepared for U. S. Atomic Energy Commission under contract no. W-7405-Eng-48

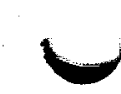




\section{DISCLAIMER}

This report was prepared as an account of work sponsored by an agency of the United States Government. Neither the United States Government nor any agency Thereof, nor any of their employees, makes any warranty, express or implied, or assumes any legal liability or responsibility for the accuracy, completeness, or usefulness of any information, apparatus, product, or process disclosed, or represents that its use would not infringe privately owned rights. Reference herein to any specific commercial product, process, or service by trade name, trademark, manufacturer, or otherwise does not necessarily constitute or imply its endorsement, recommendation, or favoring by the United States Government or any agency thereof. The views and opinions of authors expressed herein do not necessarily state or reflect those of the United States Government or any agency thereof. 


\section{DISCLAIMER}

Portions of this document may be illegible in electronic image products. Images are produced from the best available original document. 


\title{
A METHODICAL APPROACH TO TEMPERATURE \\ AND PRESSURE MEASUREMENTS \\ FOR IN SITU ENERGY-RECOVERY PROCESSES
}

\begin{abstract}
Continuous monitoring of temperature and pressure is critical to in situ energyrecovery processes. Because of the harsh environments to which the instruments will be subjected and the difficulty of emplacing them, a methodical approach to an instrumentation plan is necessary. This report describes the aspects of such a methodical approach and suggests areas that will require conside ration.
\end{abstract}

\section{INTRODUCTION}

The re are currently three projects at Lawrence Livermore Laboratory for developing methods of recovering energy from natural resources. These are in situ coal gasification, in situ shale oil recovery, and geothermal electrical power generation. The control of all three of these processes requires continuous measurement of temperature and pressure. The rates of reaction, addition of reactants, and control of flow all depend on these parameters.

Although considerable control and measurement experience exists in the power, petroleum, and chemical industries, most of this experience is with surface-located production facilities, where most of the environmental factors are easily controlled. Geothermal electrical power generation will be in a similar situation, although instruments must be protected from corrosive brines. For the in situ projects however, instrumentation will be exposed to harsh thermal, chemical, and mechanical environments. The emplacement process will be difficult and expensive and the control center will be hundreds of metres from the instruments themselves. All in all, the instrumentation problems for the two in situ projects are extensive and require a methodical approach to solutions.

That methodical approach involves three steps, which I will describe in this report. The steps are:

1. Defining the instrumentation needs and problems.

2. Determining feasibility, both technical and economic.

3. Producing the final design, fabrication, installation, and testing of the measuring instrumentation. 
The steps that must be taken to provide adequate temperature- and pressuremeasuring equipment for the in situ processes are:

1. Determining the expected temperature and pressure ranges, as well as other environments to which the measuring equipment may be exposed; determining which materials or protection may be necessary to combat the ill effects of environment on the measuring equipment.

2. Devising methods for emplacing the measuring equipment.

3. Selecting or designing temperature and pressure sensors that will reliably and accurately provide understandable data for process control; selecting or designing data reduction and control equipment that will translate the temperature and pressure information into control functions.

Temperature and Pressure Ranges and In Situ Environments

We already know that the temperature for in situ retorting of oil shale is expected to be in excess of $400^{\circ} \mathrm{C}$ and the burn front in the coal gasification process may attain $1500^{\circ} \mathrm{C}$. The temperatures will approach the natural ambient of less than $100^{\circ} \mathrm{C}$ at increasing distances from the retorting front. Pressures will exceed $7 \mathrm{MPa}$ in the coal project.

We also know that the coal gasification instrumentation will be exposed to corrosive environments that include hot water, tars, phenol, $\mathrm{SO}_{2}, \mathrm{H}_{2} \mathrm{~S}, \mathrm{CO}_{\mathrm{s}}, \mathrm{CH}_{4}$, and $\mathrm{CO}_{2}$. In both processes, the earth overburden may move because of pressure buildup or subsidence. Large dynamic stresses and movements will also occur during the explosions used to fracture the coal or oil shale beds. All these factors must be taken into account in developing an instrumentation package.

The instruments that are to be used for in situ me asurements must be made from materials that will withstand the process environments. If a protective shield is used to isolate the instruments from the reacting environment, the shield material must be constructed from resistant materials. The selection of the wrong materials can result in instrumentation failure because of corrosion or loss of instrumentation stability because of diffusion of environmental impurities into the temperature and pressure sensors. Therefore, entensive materials studies will be necessary to the preparation of an instrumentation plan.

\section{Instrumentation Emplacement}

If instrumentation sensors and cabling are emplaced before explosive fracturing, they must be mechanically protected from the ensuing shock stress and earth movement. If the instrumentation is emplaced after fracturing, it may have to be in a cased hole. It may be expedient to route the instrumentation power and signal cabling from the bottom and along the side of the fractured zone. 
The ideal emplacement method for temperature instrumentation is a cased hole through which the temperature sensor can be lowered and raised from the surface. This not only gives accurate temperature distribution data but also facilitates maintenance and replacement of the sensor and its cabling.

Pressure transmission tubes can lead to the surface to give pressure distribution data.

Unfortunately, using separately drilled and cased instrumentation holes, while desirable from the technical standpoint, is the most costly approach.

Sensing Devices, Data Reduction Equipment, and Process Controllers

\section{Temperature Sensors}

Four standard types of thermocouples are available commercially to measure the temperature ranges of interest in the in situ processes. They are shown in Table 1.

Table 1. Thermocouples for in situ processes.

\begin{tabular}{ccc}
\hline ISA & $\begin{array}{c}\text { Maximum } \\
\text { temperature } \\
\left({ }^{\circ} \mathrm{C}\right)\end{array}$ & $\begin{array}{c}\text { Millivolts } \\
\text { at } 1000^{\circ} \mathrm{C}\end{array}$ \\
\hline $\mathrm{K}$ & 1260 & 41.269 \\
$\mathrm{R}$ & 1540 & 10.503 \\
$\mathrm{~S}$ & 1540 & 9.585 \\
$\mathrm{~B}$ & 1800 & 4.833 \\
\hline
\end{tabular}

anstrument Society of America.
Choosing the rmocouples for in situ measurements requires that factors of maximum temperature, sufficient signal, and cost be balanced.

These the rmocouples work relatively well in oxygen environments but are gradually changed by a wide range of impurities so that their signal does not reflect the actual temperature. Even thermocouples sheathed in metal and ceramics have shown degradation effects at long times at high temperatures.

Resistance thermometers of metallic construction are very accurate and produce large signal changes with temperature change. They are, however, usable only to 600 to $800^{\circ} \mathrm{C}$. They also are degraded by mechanical deformation and shock loading. Certain high-temperature ceramics, however, change resistance with temperatures and probably could be developed into highly stable in situ sensors.

Magic Wire $^{*}$ is a thermocouple-wire-based transducer that is embedded in a ceramic material and sheathed with a metallic covering. The ceramic has a negative coefficient of electrical resistance (i.e., it becomes more conductive with increasing temperatures): At high temperatures the the rmocouple-wire pair shorts across the conductive ceramic, forming a temperature-measuring junction. A third wire is used

\footnotetext{
Reference to a company or product name does not imply approval or recommendation of the product by the University of California or the U. S. Atomic Energy Commission to the exclusion of others that may be suitable.
} 
to locate electrically the position of this short. This device not only could record burn front temperature but also could locate its position. The temperature limit of this material is $1100^{\circ} \mathrm{C}$; it possesses most of the qualities of ISA type $\mathrm{K}$ thermocouples. Electrical time domain reflectometry (TDR) can be used in a technique similar to the Magic Wire method. The setup is much the same as the Magic Wire, except that the wires in the cable are not thermoelements. As a result, the ceramic itself becomes the thermometer. Its resistance decreases with increasing temperature. TDR can be used to locate the point of lowest resistance (i. e. , the point of maximum temperature). With this technique, the transit time of an electrical pulse is related to the distance to that point, and its amplitude is related to the resistance.

TDR can also be used to locate a set temperature. A TDR cable could be constructed of a metal that melts at a desired temperature. Upon reaching the melting point the wires would melt and fuse together. TDR then would be employed to find the location of this temperature point.

These electrical TDR devices do not presently exist.

Acoustic the rmometry exploits the change in sonic velocity that occurs with temperature. A metallic bar with a send-receive acoustic transducer mounted at one end can monitor the average transit time of a sonic pulse sent down the bar and reflected back from the far end. The average temperature of the bar can be calculated. from the known velocity-temperature relationship for that metal. Temperature differences in the bar can be measured by placing notches at regular intervals along the bar. Each notch will reflect a part of the sonic pulse, and the times between reflected signals can be associated with the average temperatures between notches.

The accuracy of this type of device is limited by the accuracy of measuring the short time spans between notches. In addition, intergranular corrosion caused by harsh environments will severely distort the signal. A portion of the signal will be lost to the surrounding solids at points of contact, thus reducing signal magnitude.

\section{Pressure Transducers}

Pressure transducers are available commercially that can withstand the temperatures of the in situ processes. However, they are made of materials that would corrode severely in the chemical environment. They would also be damaged by mechanical shock and the forces of earth movements. The se problems can be eliminated by bringing the pressure environment up to the surface. Making measurements at the surface would also eliminate the need for the more expensive temperatureresistant transducers.

\section{Data Reduction Equipment and Process Controllers}

This type of equipment has already been developed for surface industrial plants. Choosing the appropriate equipment for the in situ processes requires knowledge of expected signal levels, process actuators, process servomechanisms, and 
requirements for process continuation. This portion of the instrumentation is complex, but it has the advantage of fewer unknowns.

\section{FEASIBILITY STUDIES}

Once methods have been selected for instrumentation of the in situ processes, a research and development program is necessary to insure the feasibility of the chosen techniques. Prototypes must be fabricated and simulation tested, and materials and environmental aspects must be reviewed and tested to prove reliability.

The costs of candidate methods must also be determined. All other things being approximately equal, the cost may be the major factor in selecting the method to be employed. However, the in situ temperature and pressure monitoring is sufficiently important to the processes that its effectiveness should not be risked for the sake of a cost savings.

\section{FINAL DESIGN, FABRICATION, INSTALLATION, AND TESTING}

When an instrumentation plan has been developed that meets all the criteria and its feasibility has been established, the final design specifications are prepared and the instrumentation is fabricated. It is then installed in situ and simulation tested until its reliability is established.

\section{SUMMARY}

In situ process temperature and pressure measurements are critical to the process. Because they are performed in situ, the instrumentation is subjected to harsh thermal, chemical, and mechanical environments, the extent and effects of which are not completely known.

To solve these problems requires a methodical approach that defines the needs and problems, determines the feasibility of various plans, and finally provides and tests the instrumentation package. Such an approach calls for a significant expenditure of time and money because of the complexities and unknowns involved. 


\section{BIBLIOGRAPHY}

1. G. H. Higgins, A New Concept for In Situ Coal Gasification, Lawrence Livermore Laboratory Rept. UCRL-51217 (1972).

2. A. E. Lewis, The Outlook for Oil Shale, Lawrence Livermore Laboratory Rept. UCRL-75242 (1974).

3. Temperature - Its Measurement and Control in Science and Industry (Reinhold Publishing Co., 1942).

4. C. M. Herzfeld, Ed., Temperature - Its Measurement and Control in Science and Industry (Reinhold Publishing Co., 1962), vol. 3, pt. 2.

5. H. H. Plumb, Ed. , Temperature - Its Measurement and Control in Science and Industry (Instrument Society of America, 1971), vol 4, pts. 1, 2, 3.

6. Manual on the Use of Thermocouples in Temperature Measurement, STP 470 (American Society for Testing and Materials, Philadelphia, Penn., 1970).

7. The Omega Temperature Measurement Handbook (Omega Engineering, Inc., Stamford, Conn., 1974).

8. "Reluctive Inductive and Eddy Current Pressure Transducers", Meas. and Data 8 (4), 64 (1974.

9. "Capacitive Pressure Transducers", Meas. and Data 8 (3), 84 (1974).

10. "Potentiometric Pressure Transducers", Meas. and Data 8 (1), 109 (1974).

11. J. R. Mallon, "The Solid State Approach to Pressure Measurement", Meas. and Data 6 (6), 75 (1972).

12. "Strain Gage Pressure Transducers," Meas. and Data 7 (2), 114 (1973).

NOTICE "This report was prepared as an account of work sponsored by
the United States Government. Neither the United States nor the United States Atomic Encrgy Commission, nor any of their employees, nor any of their contractors, subcontractors, or their employees, makes any warranty, express or implied, or assumes any legal liability or responsibility for the accuracy, completeness or usefulness of any information, apparatus, product or process disclosed, or represents that its use would not infringe privattlyowned rights."

$\mathrm{JMB} / \mathrm{cb}$ 